\title{
Covid-19 on Route of the Fourth Industrial Revolution
}

\section{Luis Bonilla-Molina ${ }^{1,2}$}

Published online: 15 August 2020

(C) Springer Nature Switzerland AG 2020

Keywords Covid-19 · Pandemic · Global Pedagogical Blackout · Fourth Industrial Revolution · Lockdown · Quarantine · Home schooling · Working from home - Educational engineering $\cdot$ Capitalism $\cdot$ Neoliberalism $\cdot$ Anti-capitalism $\cdot$ Resistance

\section{Global Pedagogical Blackout}

Since 2015 I have been talking about an imminent Global Pedagogical Blackout (GPB) as part of a transitional frame between the Third and Fourth Industrial Revolution (Bonilla-Molina 2016, 2017). The Global Pedagogical Blackout was progressively realized with (a) the de-pedagogization of the reality of education; (b) the construction of an evaluative culture (PISA, ${ }^{1}$ PIAAC, ${ }^{2}$ LLECE $^{3}$-UNESCO tests, TIMMS, ${ }^{4}$ assessments of the national institutes for the assessment of educational quality, among others) justified by notions of quality and relevance; (c) the construction of a paradigm based on the 'crisis of the education system,' (d) educational divestment, especially in terms of technological updating (Internet, hardware, software), which was turning public schools and universities into museums of the past; (e) the discursive hegemony of the educational quality of Sustainable Development Goal Number $4^{5}$ in public policies linked to education, in contrast to (f) an outdated curriculum paired to an updated

\footnotetext{
${ }^{1}$ Programme for International Student Assessment. See https://www.oecd.org/pisa/. Accessed 1 July 2020.

${ }^{2}$ Programme for International Assessment of Adult Competencies. See https://www.oecd.org/skills/piaac/. Accessed 1 July 2020.

${ }^{3}$ Latin American Laboratory for The Assessment of Educational Quality (LLECE) is attached to UNESCO's Regional Office of Education for Latin America and the Caribbean (OREALC). See https://unesdoc.unesco. org/ark:/48223/pf0000162674. Accessed 1 July 2020.

${ }^{4}$ Trends in International Mathematics and Science Study (TIMMS) works under the International Association for Educational Performance Assessment (IEA). See https://timssandpirls.bc.edu/timss-landing.html. Accessed 1 July 2020.

${ }^{5}$ See https://sdgs.un.org/goals. Accessed 1 July 2020. For an author's analysis of Sustainable Development Goal Number 4, see Bonilla-Molina (2017).
}

Luis Bonilla-Molina

luisbonillamolina.62@gmail.com

1 University of Panama, Panama City, Panama

2 International Center of Investigations 'Other voices in Education' (CII-OVE/CLACSO), Caracas, Venezuela 
model of content unable to keep up with the accelerating innovation; and (g) the impetus for a conversion of the teaching profession into curricular administration.

Following Covid-19 lockdowns and transitions to online education, the Global Pedagogical Blackout is now more clearly evidenced as a consequence of the transformation of the capitalist mode of production through the acceleration of scientific-technological innovation (Bonilla-Molina 2020a, b, c, d). The preventive quarantine has been used to enhance the construction of hegemony upon a new model of education, virtual education at home (Bonilla-Molina 2020 e, f), which is already in proposal by the Inter-American Development Bank (IDB), World Bank, Organization for Economic Development (OECD), and the US Trump administration.

The contingent shift towards a virtual home education model is closely linked to the Covid-19 pandemic, yet this opportunity accelerates the construction of hegemony for near future. In just few months, educational neoliberalism has mainstreamed tensions between face-to-face education in schools and virtual education at home in global public discourse. This is a false dichotomy because virtuality can complement face-to-face educational process without replacing them. As Paulo Freire (1972) emphasized, we all learn together. Certainly, schools will gradually reopen their doors in a few weeks or months, but educational neoliberalism has already created the illusion that schools are outdated-an illusion which is a useful justification for capital to start a new phase of the destruction of public schools.

The 'home school' or 'home education' model has been making its way for decades, as capital bet to lower the costs of sustaining national and local school equipment. In the $1980 \mathrm{~s}$, the paradigm of the 'education society' was promoted, which sought to transfer the responsibilities of the State to communities and families; the central idea was for families to pay for their children's education and for the state to address only those lagging behind. Presented through the discourse of citizen co-responsibility, this initiative gained a special push with the appointment of the Trump administration's director of education Betsy DeVos, a militant devotee of the home education model (Bonilla-Molina 2020g).

During the Covid-19 pandemic and its social distancing context, parents and families are abruptly given the responsibility to endow their students with equipped computers, the Internet, access to platforms, and a 'virtual pedagogy.' This is not a temporary situation as we are led to believe, but an integral part of the political and ideological architecture of education and schooling that has been in the making for a long time (Bonilla-Molina 2020g). Together with initiatives to make the home education model possible, the world of work has inevitably begun to change (Bonilla-Molina 2020h).

The Global Pedagogical Blackout is the beginning of a planetary-scale process of social reengineering to reorder the world of work, consumption, sociability, and governance. Cognitive capitalism changes models of consumption, trade, merchandise, (material and immaterial) production, sociability, and education. My view is that the 'family home' will play a central role in this reordering. 


\section{The Home, the New Laboral Center}

Work in the First and Second Industrial Revolution had industrial factories for production, and offices for the bureaucracy, as the central places of employment. A good amount of informal and artisanal work was also organized around these axes. However, the Third Industrial Revolution began to reorient this trend. In the last decades, telework from home has become a new work phenomenon.

The Eurofound and the International Labor Organization report entitled 'Working anytime, anywhere: The effects on the world of work' (2017) noted that, depending on the country, telework ranged from 2 to $40 \%$ and in its full range of expression would mostly fall into the range of informal or flex-based work. According to the report, this implies a drastic change in the organization of work time, which in many cases can exceed the maximum legally permitted workload. The most relevant part of the report is that telework shows a clear trend towards expansion over the next five years. The experience of social isolation has led many governments to consider quick development of telework-related legislation, thus reallocating various office tasks to the once 'private' space of the home.

\section{The Home Epicenter of Consumption}

After the Second World War, the dominating trade model implied that the goods went to the consumer. During the 1970s, crises of overproduction and oil prices began to reorient consumption towards shopping malls, prompting the consumer to go where the goods were. Scheduled obsolescence of goods and slow incorporation into consumption of those living without electricity, education, or little drinking water, partially solved the problem of failed capitalist gain projections.

The Internet made way for online commerce or e-commerce, which concentrated consumption in a new place: the home. Social media and increased connectivity have strengthened the tendency to relocate consumption. According to the 'Global Consumption Report on e-Commerce: Key Figures Globally' (E-Commerce Nation 2018), annual average online purchases vary by zones, with Asia having the largest number of 22.1 online purchases per year. North America had 19 online purchases per year, Western Europe 18.4, and Austria and New Zealand 16.1. Areas with the lowest numbers of online purchases per year are Latin America with 9.2, Africa and the Middle East 11, and Eastern Europe and Russia 11.9. The report predicted that these numbers were to exponentially grow by 2020 . Covid-19-induced lockdowns and quarantines have further enhanced online mode of consumption, bringing medicines, food, non-perishable products, books, technology, among other things, from commercial premises to customer's doorstep.

\section{Trade and Finance from Home}

The 2008 financial crisis showed capital's ability to move from place to place using online commerce. This trend has been accentuated in recent years, and today many commercial and financial transactions are done from home. This dynamic gave way to Business-to-Business e-commerce that reported as early as January 2020 a $150 \%$ growth compared with 2017 (We are social 2020). This is more than evident in the 
Asia Pacific, which today is one of the most important dynamizers of the capitalist economy, and where $80 \%$ of operations are carried out in this format. Economy and consumption have moved to an online model, which centrally includes working from home.

\section{Reordering Sociability}

Bars, cinemas, restaurants, and other places of leisure and fun play a decisive role in human encounters and the construction of sociability. Social networks have been reconfiguring these human needs for a while, and much of the dialogue and the construction of affinities is now done digitally. However, these trends do not include everyone. The Hootsuite Report (Cooper 2020) demonstrating '140 social media statistics that are important to marketers in 2020 ' notes that $59 \%$ of the world's population or some 4.540 million people have access to the Internet, $84 \%$ of whom use social media. The report indicates that $50 \%$ of the world's population use some social network and/or platform, which means that the other 50\%, among which are students, parents, and teachers, have no online experience. Clearly, these statistics significantly influence home education initiatives within the framework of the Covid19 pandemic.

\section{Citizen Security, Ecological Crisis, and the Home}

State-of-the-art technological developments, especially those associated with artificial intelligence, nanotechnology, facial biometric recognition, and metadata analysis, are being experimented on for social control, with China as a leader in the field. The idea of big brother becomes indispensable from production and consumption in the Fourth Industrial Revolution. Such developments cause numerous problems, threaten to leave half of global population on the economic periphery, and increase social discontent, unrest, and revolt. To avoid revolutions, the home has become the primary control unit. This global governance model has been furthered with social distancing and quarantine introduced during the Covid-19 pandemic. 'Stay at Home' is a form of social control and an experiment in how long the population will endure under the aegis of induced fear.

Similarly, a dominant discourse related to the global ecological crisis is now being constructed around the idea that citizens confined in their homes have caused a significant reduction in pollution. In this discourse, which blames the people rather than the capitalist system, the solution is not to overcome the profitfocused model but to reduce people's mobility (Bonilla-Molina 2020i). The confinement at home is presented as a determining factor in a solution to the ecological crisis.

The twenty-first century cognitive and transnational capital/capitalism seems to be revaluing the role of a 'family home' in the economy, consumption, work, and education. The home appears as one of the potential new epicenters for social reengineering. This process of assembly is denounced within the Global Pedagogical Blackout. This does not imply that there should not be any 'virtual pedagogies,' more so that the essence of pedagogy, the human encounter, is being threatened. 


\section{Covid-19 and Educational Reengineering}

Covid-19 lockdowns and quarantines have opened up various strategies and approaches focused on the model of home education. More often than not, this 'transition' fails to take into account economic, social, and technological inequalities. UNESCO's pre-pandemic (2019) data is frightening: of the 1.730 million children out of school, 800 million had no computer and approximately 700 million had no Internet connection. Just before the global lockdown, 258 million school-aged children and adolescents were out of school. Adding these numbers, more than a billion children and young people have remained out of (online) school coverage during the Covid-19 pandemic.

The world has a bit over 7.7 billion inhabitants, 1 billion of which do not have access to electricity (IEA, IRENA, UNSD, WB, WHO 2019). According to the International Labour Office (2020), the world's employed population before Covid19 was 3.3 billion. Two billion people were in informal employment, 1.2 billion of which were in highly unstable (day-to-day) employment. Teachers account for ca $5 \%$ of the world's employment. Between 75 and $85 \%$ of public education expenditure goes to the teaching payroll. Based on the promise of reducing this expenditure, the model of home education becomes a Trojan horse to initiate a neo-privatization of education.

However, the home education model has highlighted a number of problems. The first problem is pedagogical: the model of frontal classroom education, focused on the blackboard, plays little or no role in new models of online education. Interactivity, multimedia, and brevity of ideas characteristic for online communications do not fit well with schools focused on orality and classical written forms. Schools are not equipped with technological infrastructure (computers, cameras, Internet connectivity) and platforms offered by ministries of education are often inadequate. Lot of online educational content fails to appropriately utilize digital affordances. In many instances, the home education model is not more than an online extension of Freire's (1972) model of banking education.

Second, teachers have little and/or inadequate training for supporting their students at home. This is the responsibility of educational ministries and teacher training centers, which often lag behind technological and pedagogical developments. Many teachers work in institutional cultures that see technology as the enemy. This creates a clash between educational policies and realities. For instance, before the Covid-19 pandemic, documents and policies such as the 'UNESCO Guidelines for Mobile Learning Policies' (2013) were adopted in many countries, yet the use of cell phones in educational institutions was nevertheless prohibited.

Third, the false tension between virtual education and face-to-face education in schools has generated a neo-conservative wave of an uncritical defense of face-to-face schooling, ignoring its structural deficiencies in developing a Freirean model of liberating, transformative education. Fourth, the lack of understanding of global processes leading to the model of virtual education at home has generated the fatuous hope that after the end of the Covid-19 pandemic things will return to the old 'normal.' However, this return is impossible. During the pandemic, neoliberalism has sowed the idea of obsolescence of the face-to-face school deeply into public discourse. The world of employment is also changing, and the old Newtonian educational machine built for capital's requirements within the framework of the First and Second Industrial Revolution is no longer relevant and/or needed (Bonilla-Molina 2020j). 


\section{The Alternatives}

The only way to build alternatives is to come together and think of a different education. This requires building philosophical foundations, principles, and values for a new school, and developing practical strategies to instrumentalize these ideas. Now more than ever, the pandemic world requires a unity of teachers, guilds, trade unions, academics, collectives, companions of popular education, and everyone else interested in the future of education. Another world is possible. That is why the International Contact Group ${ }^{6}$ supports the first American summit of anti-neoliberal educators in bringing together teachers that resist and fight neoliberal educational policies and practices within the region. We all have our own ideas about what will come and how to shape the future, but times of individual heroes are irreversibly gone. The future of education during and after Covid-19 requires global collective action.

Acknowledgments This article was written for Postdigital Science and Education in May 2020. The first draft of the article, written in Spanish language, was published as a blog post (Bonilla-Molina 2020k). The draft was translated by Jorge F. Rodriguez, reviewed, and extensively edited in collaboration between the author, the translator, and the PDSE editorial team.

Postdigital Science and Education extends special thanks to Jorge F. Rodriguez, who quickly and masterfully translated the article, thus allowing the journal to offer a truly global perspective on the Covid19 pandemic.

\section{References}

Bonilla-Molina, L. (2016). Apagón Pedagógico Global (APG). Las reformas educativas en clave de resistencias. Viento Sur, 147, 21 August. https://vientosur.info/apagon-pedagogico-global-apg-lasreformas-educativas-en-clave-de-resistencias/. Accessed 1 July 2020.

Bonilla-Molina, L. (2017). El ODS-4 en la perspectiva de la pedagogía radical de las resistencias. Revista Cientifica RUNAE, 2, 123-140 http://repositorio.unae.edu.ec/bitstream/56000/232/1/runae\%202017-12125-142ed.2-\%20diciembre\%202017.pdf. Accessed 1 July 2020.

Bonilla-Molina, L. (2020a). En casa y sin tocar a los otros: coronavirus o reingeniería social a escala planetaria. https://luisbonillamolina.wordpress.com/2020/03/16/en-casa-y-sin-tocar-a-los-otroscoronavirus-o-reingenieria-social-a-escala-planetaria/. Accessed 1 July 2020.

Bonilla-Molina, L. (2020b). La escuela y la universidad en el capitalismo de la primera y segunda revolución industrial. https://luisbonillamolina.wordpress.com/2020/03/26/la-escuela-y-la-universidad-en-elcapitalismo-de-la-primera-y-segunda-revolucion-industrial/. Accessed 1 July 2020.

Bonilla-Molina, L. (2020c). La cultura evaluativa y la virtualización educativa: dos tenazas del capitalismo cognitivo de la tercera revolución industrial. https://uisbonillamolina.wordpress.com/2020/03/26/lacultura-evaluativa-y-la-virtualizacion-educativa-dos-tenazas-del-capitalismo-cognitivo-de-la-tercerarevolucion-industrial/. Accessed 1 July 2020.

Bonilla-Molina, L. (2020d). Coronavirus: Google y la NASA en la reingeniería educativa. https://luisbonillamolina.wordpress.com/2020/03/26/coronavirus-google-y-la-nasa-en-la-reingenieriaeducativa/. Accessed 1 July 2020.

Bonilla-Molina, L. (2020e). Pongámonos serios ¿Educación virtual en casa?. https://luisbonillamolina. wordpress.com/2020/04/10/pongamonos-serios-cada-familia-una-escuela/. Accessed 1 July 2020.

Bonilla-Molina, L. (2020f). Los desaparecidos y torturados por el modelo global de educación en casa. https://luisbonillamolina.wordpress.com/2020/04/27/los-desaparecidos-y-torturados-por-el-modeloglobal-de-educacion-en-casa/. Accessed 1 July 2020.

\footnotetext{
${ }^{6}$ See https://www.coe.int/en/web/edc/international-contact-group. Accessed 1 July 2020.
} 
Bonilla-Molina, L. (2020g). Coronavirus, nuevas profesiones y máquina educativa newtoniana. https://uisbonillamolina.wordpress.com/2020/04/06/coronavirus-nuevas-profesiones-y-maquinaeducativa-newtoniana/. Accessed 1 July 2020.

Bonilla-Molina, L. (2020h). El presupuesto para la nómina docente en el centro de interés de la neo privatización educativa. https://uisbonillamolina.wordpress.com/2020/04/08/el-presupuesto-de-lanomina-docente-en-el-centro-de-interes-de-la-neo-privatizacion-educativa/. Accessed 1 July 2020.

Bonilla-Molina, L. (2020i). Avengers, Coronavirus y cambio climático. https://luisbonillamolina.wordpress. com/2020/03/20/avengers-coronavirus-y-cambio-climatico/. Accessed 1 July 2020.

Bonilla-Molina, L. (2020j). Coronavirus, nuevas profesiones y máquina educativa newtoniana. https://luisbonillamolina.wordpress.com/2020/04/06/coronavirus-nuevas-profesiones-y-maquinaeducativa-newtoniana/. Accessed 1 July 2020.

Bonilla-Molina, L. (2020k). El COVID-19 en la ruta de la cuarta revolución industrial. https://luisbonillamolina.wordpress.com/2020/05/15/el-covid-19-en-la-ruta-de-la-cuarta-revolucionindustrial/. Accessed 1 July 2020.

Cooper, P. (2020). 140 estadísticas de redes sociales que son importantes para los mercadólogos en 2020. Hootsuite, 20 April. https://blog.hootsuite.com/es/125-estadisticas-de-redes-sociales/. Accessed 1 July 2020.

E-Commerce Nation (2018). Informe global de consumo sobre ecommerce: cifras clave a nivel mundial. 5 June. https://www.ecommerce-nation.es/estudio-ecommerce-cifras-tendencias/. Accessed 1 July 2020.

Eurofound and the International Labour Office. (2017). Working anytime, anywhere: The effects on the world of work. Luxembourg and Geneva: Publications Office of the European Union, and the International Labour Office. https:/www.ilo.org/wcmsp5/groups/public/\%2D\%2D-dgreports/\%2D\%2D-dcomm/\%2 D\%2D-publ/documents/publication/wcms_544138.pdf. Accessed 1 July 2020.

Freire, P. (1972). Pedagogy of the oppressed. Harmondsworth: Penguin Education Specials.

IEA, IRENA, UNSD, WB, \& WHO. (2019). Tracking SDG 7: The Energy Progress Report 2019. Washington, DC: International Bank for Reconstruction and Development and The World Bank. https://sustainabledevelopment.un.org/content/documents/2019_Tracking_SDG7_Report.pdf. Accessed 1 July 2020.

International Labour Office. (2020). World employment and social outlook: Trends 2020. Geneva: International Labour Office. https://www.ilo.org/wcmsp5/groups/public/\%2D\%2D-dgreports/\%2D\%2Ddcomm/\%2D\%2D-publ/documents/publication/wcms 734455.pdf. Accessed 1 July 2020.

UNESCO (2013). Directrices de la UNESCO para las políticas de aprendizaje móvil. Paris: a Organización de las Naciones Unidas para la Educación, la Ciencia y la Cultura. http://www.unesco. org/new/fileadmin/MULTIMEDIA/HQ/ED/ICT/images/114_13_ED_UNESCO_Policy_Guidelines_for_ Mobile_Learning_S.pdf. Accessed 1 July 2020.

UNESCO. (2019). UIS fact sheet no. 56. Paris: UNESCO. http://uis.unesco. org/sites/default/files/documents/new-methodology-shows-258-million-children-adolescents-and-youthare-out-school.pdf. Accessed 1 July 2020.

We are social. (2020). Digital in 2019. New York: We are social. https://wearesocial.com/global-digitalreport-2019. Accessed 1 July 2020. 